\title{
Coexistence of algae and bacteria: a test of the carbon hypothesis
}

\author{
Tanguy Daufresne $^{1, *}$, Gerard Lacroix ${ }^{2}$, David Benhaim ${ }^{3}$, Michel Loreau $^{4}$ \\ ${ }^{1}$ INRA, Department of Wildlife Ecology and Behavior (CEFS), Chemin de Borde Rouge, BP 52627, \\ 31326 Castanet-Tolosan Cedex, France \\ ${ }^{2}$ UMR 7618, Bioemco, Biogeochimie et écologie des milieux continentaux, Ecole Normale Supérieure, 46 rue d'Ulm, \\ 75230 Paris Cedex 05, France \\ ${ }^{3}$ Intechmer, Digue de Collignon, BP 324, 50103 Cherbourg Cedex, France \\ ${ }^{4}$ McGill University, Department of Biology, 1205 avenue Docteur Penfield, Montreal, Québec H3A 1B1, Canada
}

\begin{abstract}
The competition between algae and aquatic bacteria for inorganic nutrients puts some constraints on the coexistence of these 2 essential groups in the water column. Based on competition and stoichiometry theories the carbon hypothesis states that, since bacteria are better competitors for nutrients, they may drive themselves to carbon (C)-limitation, so coexistence would naturally arise between nutrient-limited algae and C-limited bacteria. We tested the carbon hypothesis in 24 closed aquatic microcosms with 4 different artificial media inoculated with an alga (Scenedesmus obliquus) and a natural bacterial community. We monitored algal and bacterial growth, coexistence over time, and the limitation status of $S$. obliquus and the bacterial community. In all 24 microcosms, both the algal and the bacterial communities showed a net growth phase followed by a plateau, reflecting stable coexistence over time. At the plateau, the algae were limited by nitrogen $(\mathrm{N})$ and/or phosphorus $(\mathrm{P})$, depending on the medium, whereas the bacteria were co-limited by organic $\mathrm{C}$ and the nutrients $\mathrm{N}$ and $\mathrm{P}$. We argue that these results are consistent with the carbon hypothesis, and we discuss the fact that bacteria were co-limited instead of purely C-limited in light of the resource-ratio theory. Our results provide evidence that, even in the absence of factors preventing competitive exclusion (e.g. spatial heterogeneity, temporal fluctuations, predators), phytoplankton and bacteria can coexist and sustain basic ecosystem functions, namely primary production and nutrient cycling.
\end{abstract}

KEY WORDS: Bacterioplankton · Competition · Ecosystem persistence $\cdot$ Phytoplankton

\section{INTRODUCTION}

Primary producers and decomposers ensure the 2 basic processes of ecosystem functioning: the assembly of mineral material and energy into biomass and the return of the biomass into mineral material. The remineralization of organic detritus by decomposers provides a significant income of essential nutrients such as nitrogen $(\mathrm{N})$ or phosphorus $(\mathrm{P})$ for primary producers in most aquatic and terrestrial ecosystems (Pomeroy 1970). However, due to a stoichiometric imbalance between the amount of detritus and decomposer biomass, decomposers usually need additional incomes of
N and P (Bosatta \& Berendse 1984, Sterner \& Elser 2002). By taking up inorganic nutrients in the water column, they compete with primary producers (Fig. 1). Competition has long been known to make the coexistence between species or between groups of species difficult. The principle of competitive exclusion states that, in the absence of facilitating factors such as predation, spatial heterogeneity of the environment, or any force preventing the system to reach equilibrium, 2 competitors can coexist in the long term only if they remain limited by different resources (Hardin 1960). This suggests that coexistence between primary producers and decomposers is in theory not granted 

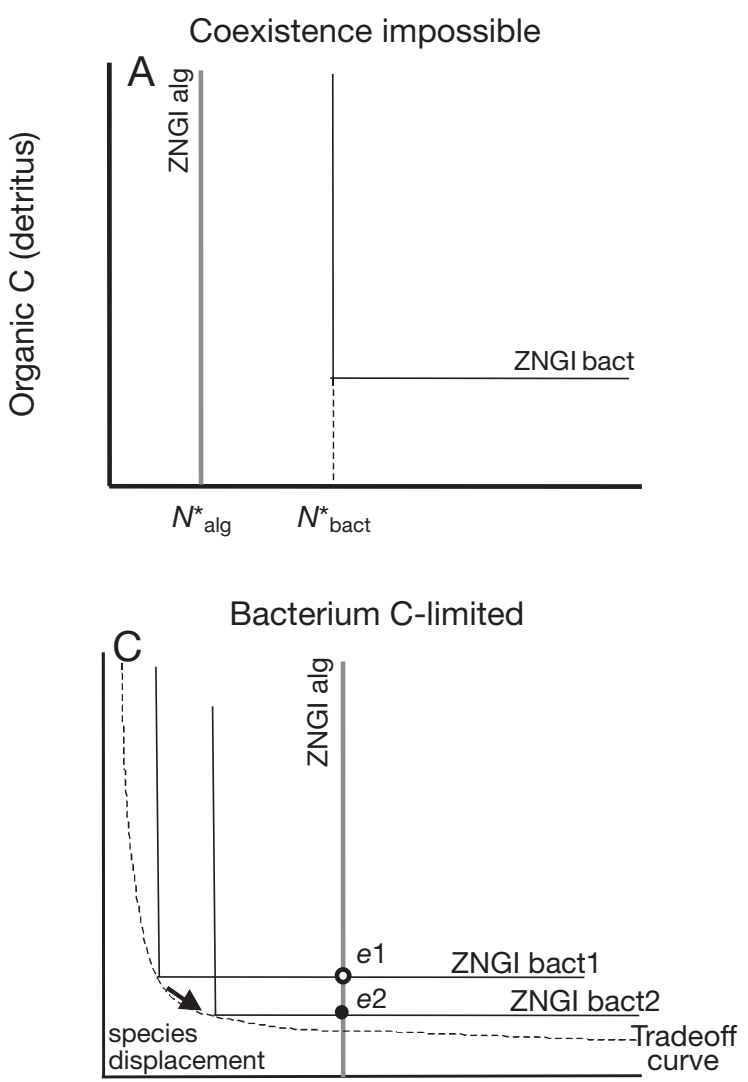

\section{Coexistence possible}

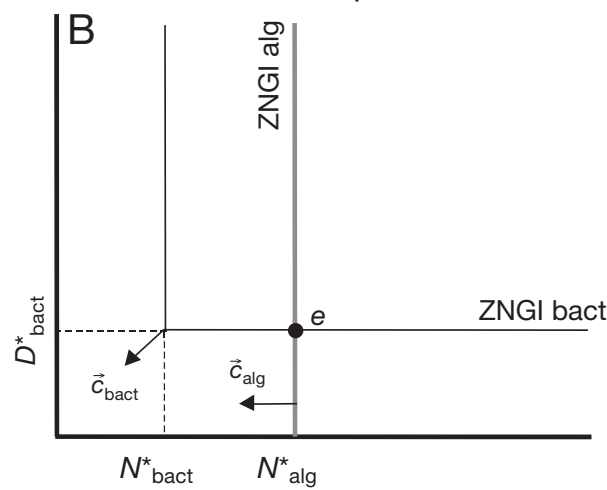

Bacterium co-limited

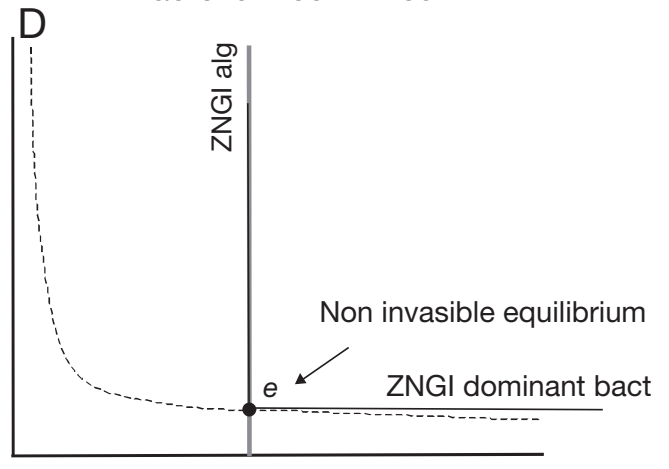

Inorganic nutrient

Fig. 1. Zero Net Growth Isocline (ZNGI) plot (Tilman 1982) of an alga and a bacterium in the nutrient versus organic carbon space, derived from the Daufresne \& Loreau (2001) model (see Appendix 1). The alga only consumes nutrient (horizontal consumption vector $\vec{C}_{\text {alg }}$ ) and its ZNGI is a straight line that hits the $x$-axis at the equilibrium (e) value $N^{*}$ alg (the $R^{*}$, sensu Tilman 1982). The bacterium consumes both organic carbon and nutrient (consumption vector $\vec{c}_{\text {bact }}$ ) and its ZNGI has a classical corner shape. (A) If the alga is a better competitor for nutrient $\left(N^{*}\right.$ alg $<N^{*}$ bact $)$ the 2 ZNGIs do not cross; hence, coexistence is impossible (Tilman 1982, Daufresne \& Loreau 2001). (B) If the bacterium is a better competitor $\left(N^{*}{ }_{\text {alg }}>N^{*}{ }_{\text {bact }}\right)$, the 2 ZNGIs cross one another and coexistence is possible (equilibrium point $e$ ). In case there is a pool of bacterial strains instead of a single bacterium, displacement by competitive exclusion leads to selection for a co-limited dominant bacterium: (C) If a resident bacterial strain (bact1) coexists at equilibrium with an alga (equilibrium point e1), any invader strain (bact2) along the carbon-nutrient uptake tradeoff (Schade et al. 2005) whose ZNGI lies closer to the ZNGI of the alga will displace bact1 (Danger et al. 2008), leading to a new equilibrium point (e2). (D) Hence, as new invaders come, the equilibrium will slide towards the ZNGI of the alga, and the bacterial strain whose ZNGI for nutrient overlaps the ZNGI of the alga is a non-invasible species (equilibrium point e). This case represents a limit case of the carbon hypothesis referred to as the carbon co-limitation hypothesis in the text

(Currie \& Kalff 1984a, Thingstad \& Pengerud 1985), which raises important questions for ecosystem persistence (Daufresne \& Loreau 2001).

In aquatic ecosystems, unicellular algae perform most of the primary production and bacteria usually ensure a substantial part of the decomposition. Referring to the principle of competitive exclusion, Currie \& Kalff (1984a) hypothesised that in freshwater, where algae are often P-limited, bacteria should be limited by a different resource, most likely organic C. Models (Bratbak \& Thingstad 1985, Thingstad et al. 1997, Daufresne \& Loreau 2001) provided some theoretical foundations to this hypothesis, referred to as the 'carbon hypothesis' by Daufresne \& Loreau (2001). The carbon hypothesis can be simply illustrated with a classic Zero Net Growth Isocline (ZNGI) based on the resource-ratio theory of competition (Tilman 1982). The ZNGIs represent the level of resource (here, either nutrient or organic C) for which mortality is balanced by population growth for a given species. The closer the ZNGI is to the axes (i.e. to zero), the more competitive the species is for the resources. We extend the pure competition model by Tilman (1982) to include the commensalist-competitive interaction between algae and bacteria in a similar fashion as proposed by Schade et al. (2005), with the interaction between phytoplanktonic N-fixers and non-fixers. An outline of the original model by Daufresne \& Loreau (2001) and the 
derivation of the ZNGIs from the model is presented in Appendix 1. Fig. 1A,B depicts the ZNGIs of an alga and a bacterium in the inorganic nutrient (e.g. $\mathrm{N}$ or $\mathrm{P}$ ) and organic $\mathrm{C}$ space. Clearly, coexistence at equilibrium is possible only if the ZNGIs cross one another (Tilman 1982), i.e. if the bacterium is more competitive than the alga for the nutrient. Daufresne \& Loreau (2001) showed that, if the alga is a better competitor, the bacterium becomes extinct. In such a case, if the alga relies on the bacterium for nutrient recycling, the system will eventually run out of inorganic nutrient and the algal population will finally collapse.

Recent theoretical studies have questioned the existence strict C-limitation for bacteria. This arises from the fact that (1) decomposition is usually performed by communities of bacteria rather than single strains, and (2) within a single strain, the occurrence of mutants is frequent. In this context, the resource-ratio theory predicts that competitive exclusion processes within the bacterial community should lead to the dominance of species that are co-limited by multiple resources (Cherif \& Loreau 2007, Danger et al. 2008). In Fig. $1 C, D$, considering a set of bacteria rather than a single bacterium, we show that co-limitation is indeed expected with the original model by Daufresne \& Loreau (2001). Assuming an interspecific tradeoff between nutrient and $\mathrm{C}$ competitive abilities, depicted by an envelope curve in the nutrient and $\mathrm{C}$ space (Danger et al. 2008), the resource-ratio theory predicts that competitive exclusion should select for a dominant bacterium which is co-limited by $\mathrm{C}$ and nutrients. Although not explicitly considered in the model by Daufresne \& Loreau (2001), co-limitation of bacteria by $\mathrm{C}$ and nutrients is not inconsistent with the carbon hypothesis. Indeed, co-limitation represents a specific case of the carbon hypothesis (the 'carbon co-limitation hypothesis') in which the alga and the bacteria have similar competitive abilities for the nutrients. This specific case is depicted in Fig. 1D, where the ZNGI of the alga and the dominant bacterium merge.

If the carbon hypothesis or the carbon co-limitation hypothesis turn out to be a general trend in aquatic ecosystems, one should expect that: (1) bacteria are generally better or equal competitors for nutrients than algae; (2) bacteria are generally carbon-limited in nature or co-limited by $\mathrm{C}$ and nutrients; (3) algae and bacteria can coexist even in the absence of facilitating factors.

Statement (1) is supported by the majority of empirical and experimental studies (Rhee 1972, Currie \& Kalff 1984b, Pengerud et al. 1987, Joint et al. 2002), even though some exceptions have been pointed out (Vadstein 1998, Havskum et al. 2003). Statement (2) remains more controversial. According to empirical and experimental studies, C-limitation is common in pelagic ecosystems (Bird \& Kalff 1984, Vadstein et al.
1989, Kirchman \& Richard 1990, Tuomi \& Kuupo 1999, Joint et al. 2002, Havskum et al. 2003). However, some studies in marine (Thingstad \& Rassoulzadegan 1995, Thingstad et al. 1998, Zohary \& Robarts 1998) as well as in freshwater ecosystems (Currie 1990, Morris \& William 1992) led to the conclusion that bacteria were not C-limited, but limited by the same nutrients as algae. In this case, there must be some factor (e.g. predation on bacteria and/or algae, or fluctuations of nutrient concentrations in the water column) that prevents competitive exclusion. In the absence of this facilitating factor, it is not clear whether algae and bacteria would be able to coexist. It seems to us of importance to clarify this point, because Statement (2) and its corollary Statement (3) have major implications for ecosystem functioning, and in particular, for ecosystem persistence and resilience to perturbations (Daufresne $\&$ Loreau 2001). For example, whether algae and bacteria form a stable assemblage per se or whether their coexistence relies on facilitating factors such as predation or resource fluctuation entails different conclusions regarding the role of functional diversity and physical disturbances in the persistence of aquatic ecosystems and in the functioning of the carbon cycle (Thingstad \& Pengerud 1985).

To shed some light on Statements (2) and (3), we designed an experiment to test whether an alga (Scenedesmus obliquus) and a community of bacteria were able to coexist and to perform primary production and efficient organic matter recycling in the absence of facilitating factors, and if so, whether the carbon hypothesis was supported. We inoculated $S$. obliquus and a community of freshwater bacteria into closed microcosms (no nutrient input or removal) containing artificial media. In these closed systems, the production of detritus by $S$. obliquus was a necessary condition for the bacteria to survive. In turn, the recycling by bacteria of essential nutrients from the detritus was necessary to provide a sustained supply of fresh inorganic nutrients to $S$. obliquus. We monitored whether $S$. obliquus and the bacteria were able to coexist in the long term and tested the factors limiting their growth at population steady-state.

We ran the experiment with 4 contrasted $\mathrm{N}$ and $\mathrm{P}$ stoichiometries. The purpose was to give the system the maximum degrees of freedom in terms of limitation for the alga ( $\mathrm{N}$ or $\mathrm{P}$ ) and the bacteria $(\mathrm{C}, \mathrm{N}$ or $\mathrm{P})$, and to cover a wide range from slightly oligotrophic to eutrophic situations.

\section{MATERIALS AND METHODS}

Microcosms and biological material. The microcosms were $500 \mathrm{ml}$ flasks (Erlenmeyer) containing 
$400 \mathrm{ml}$ of medium inoculated with Scenedesmus obliquus and a community of bacteria. We used 4 stoichiometric treatments. Each treatment was based on the regular Combo medium (Kilham et al. 1998), and depletion was obtained by diluting the concentration of $\mathrm{N}$ or $\mathrm{P}$ while the concentrations of all other nutrients remained unchanged. The 4 treatments offered contrasting conditions for algal and bacterial growth, with $\mathrm{N}$ ranging from 0.14 (N-depleted and NPdepleted) to $14 \mathrm{mg} \mathrm{l}^{-1}$ (Combo and P-depleted), $\mathrm{P}$ ranging from 0.0155 (P-depleted and NP-depleted) to $1.55 \mathrm{mg} \mathrm{l}^{-1}$ (Combo and $\mathrm{N}$-depleted), and the N:P ratio (in mass) ranging from 0.09032 ( $\mathrm{N}$-depleted) to 903.2 (P-depleted). We ran 6 microcosm replicates per treatment, which led to a total of 24 microcosms. We inoculated each microcosm with $1 \mathrm{ml}$ of a pure, nonaxenic strain of $S$. obliquus (Turpin) Kützing, cultivated in Combo medium (Kilham et al. 1998). $S$. obliquus is a well-studied species and physiological traits such as growth rate and N:P optimum ratio are documented (Rhee 1973, 1974, 1978). To obtain the $1 \mathrm{ml}$ inoculum of bacteria, we filtered temperate lake water (from lake Créteil, France) twice with $1.2 \mu \mathrm{m}$ filters (Vadstein \& Olsen 1989). We verified that bacterivorous protists were absent from the inocula and we regularly checked for the absence of protists over the whole course of the experiment. We inoculated a community of bacteria instead of a single strain because (1) decomposition requires a number of functional traits that a single strain cannot usually fulfil (Golterman 1964, Jannasch 1964, Van Wambeke \& Bianchi 1985), and (2) we wanted to make sure that the bacterial community was diverse enough so that the sliding process depicted in Fig. 1C,D could fully occur.

Within each microcosm, the medium was continuously stirred by bubbling filtered air in order to keep the medium homogeneous and prevent limitation of algal growth by $\mathrm{CO}_{2}$ and to prevent anoxia and denitrification. The photoperiod was 12:12 h light:dark. We used fluorescent tubes, yielding an average light intensity of $33 \mu \mathrm{mol} \mathrm{m} \mathrm{m}^{-2} \mathrm{~s}^{-1}$. No nutrients were added during the experiment, and evaporation was compensated weekly by deionized water. The temperature was maintained around $20^{\circ} \mathrm{C}$.

Algal and baterial dynamics before steady-state. The microcosms were inoculated with the algal culture and the bacteria at the beginning of the experiment (time $t_{0}$ ). Algae were counted weekly under a microscope, using a Thomas counting chamber. Bacteria were counted every other week with an epifluorescence microscope after filtration with $0.2 \mu \mathrm{m}$ filters and staining with 4',6-diamidino-2-phenylindole (DAPI) (Porter \& Feig 1980). Sampling of $2 \mathrm{ml}$ water from 3 randomly chosen microcosm replicates for each treatment was performed under axenic conditions in order to prevent infection of the microcosms by exogenous bacteria and/or protists. We estimated the algal biovolume by multiplying the number of counted cells by the mean cell volume. The mean cell volume was calculated from 30 randomly chosen cells, assuming ellipsoidal shapes. Bacterial biovolume was estimated directly by counting 'bacterial entities' (i.e. single cells or chains of cells) in 2 size classes, $<2 \mu \mathrm{m}$ and $>2 \mu \mathrm{m}$. The volume of each size class was estimated from 30 randomly chosen entities, assuming a tubular form.

Coexistence at steady-state. Algal and bacterial dynamics were monitored until we observed stabilisation of algal biomass in all the microcosms, i.e. until algal biomass did not significantly increase or decrease further over several sampling events. We focused on algal rather than bacterial biomass because we assumed that, due to their shorter generation time, bacteria would adjust to detritus production, and hence algal demography should lead the dynamics of the system. Such a stabilisation was achieved in all the microcosms before time $t_{1}$ (11 wk after inoculation). We assumed that steady-state coexistence was met if both Scenedesmus obliquus and the bacteria sustained positive biomass at $t_{1}$. At time $t_{1}$, we sampled algal and bacterial biomass in each microcosm, and we compared biomasses across the 4 media using a randomised block analysis of variance (ANOVA), followed by pairwise post-hoc tests (Tukey's compromise) for each treatment (Combo, N-, P- and NP-depleted media), taking into account the block effect (variation among microcosm replicates). The data were log-transformed to normalise the residuals.

Limitation status of Scenedesmus obliquus and bacteria at steady-state. At time $t_{1}$, a $50 \mathrm{ml}$ aliquot of each microcosm was collected and distributed over five $10 \mathrm{ml}$ flasks in order to test for nutrient or C-limitation. Glucose (C-test), N (N-test), P (P-test), or all 3 combined (NPC-test) were added, except for the control. $\mathrm{N}$ addition amounted to $85.01 \mathrm{mg} \mathrm{l}^{-1}$ as a final concentration in the $\mathrm{N}$ - and NPC-tests, $\mathrm{P}$ addition amounted to $8.71 \mathrm{mg} \mathrm{l}^{-1}$ as a final concentration in the P- and NPC-tests, and glucose addition amounted to $55 \mathrm{mg} \mathrm{l}^{-1}$ as a final concentration in the C- and NPC-tests. After $7 \mathrm{~d}$ incubation (at time $t_{2}$ ), we measured algal density and bacterial biovolume. We assumed that algal density was a good proxy for biomass since the variability in cell sizes was low. Cell sizes of bacteria varied a lot after nutrient addition, and we assumed that, in this case, biovolume was a better proxy for biomass. For each test, we derived the relative growth rate as the ratio of biomass measured in the test over the biomass mea- 
sured in the control. In the case of limitation by a given resource (glucose, $\mathrm{N}$ or $\mathrm{P}$ ) we expected to notice a significantly higher relative growth rate following resource supplementation. Note that, since relative growth was calculated from a biomass difference, the limitation tested here was of the 'systemic' type (sensu Thingstad \& Rassoulzadegan 1995). In the case of co-limitation by 2 or 3 resources, we expected to measure a higher relative growth rate when adding all 3 resources. For each treatment (Combo, N-, P- and NP-depleted), we compared the relative growth rates across the 4 limitation tests $(\mathrm{C}$-, $\mathrm{N}-$, P- and NPC-tests). The comparison was performed using a randomised block ANOVA, followed by pair-wise post-hoc Scheffé's tests, taking into account the block effect (variation among microcosm replicates). The data were log-transformed to normalise the residuals.

\section{RESULTS}

\section{Algal and bacterial dynamics and coexistence at steady-state}

In all 24 microcosms, Scenedesmus obliquus and the bacterial community showed a growth phase after inoculation, followed by a plateau (Fig. 2). The plateau was reached on average after $4 \mathrm{wk}$ for the Combo and after 2 wk for the 3 other treatments. Once the plateau was reached, we did not notice any significant change in biomass for the whole time of the experiment (11 wk). Preliminary experiments, which ran for over $20 \mathrm{wk}$, showed the same pattern for both algae and bacteria. This suggests that bacteria efficiently recycled nutrients within the microcosms and that there was no competitive exclusion affecting the algae or the bacteria. This result was consistent across the 4 media. In contrast, steady-state biomass at time $t_{1}$ differed across the media, as depicted in Fig. 3. For S. obliquus, biomass was lowest in the N- and NP-depleted media, whereas it was almost 2-fold higher in the P-depleted medium and more than 20-fold higher in Combo. The bacterial biomass varied less dramatically across the media and appeared to be more sensitive to N:P ratios than to nutrient concentrations. Indeed, bacterial biomass was lowest in the $\mathrm{N}$-depleted medium and highest in the P-depleted medium, with an intermediate value for Combo despite much higher algal density (Fig. 3). As a consequence, we observed a highly significant effect of the nutrient treatments on the algal:bacterial biomass ratio. This ratio was very low in the P-depleted media, intermediate in the $\mathrm{N}$ - and NP-depleted media, and significantly higher in the Combo medium.

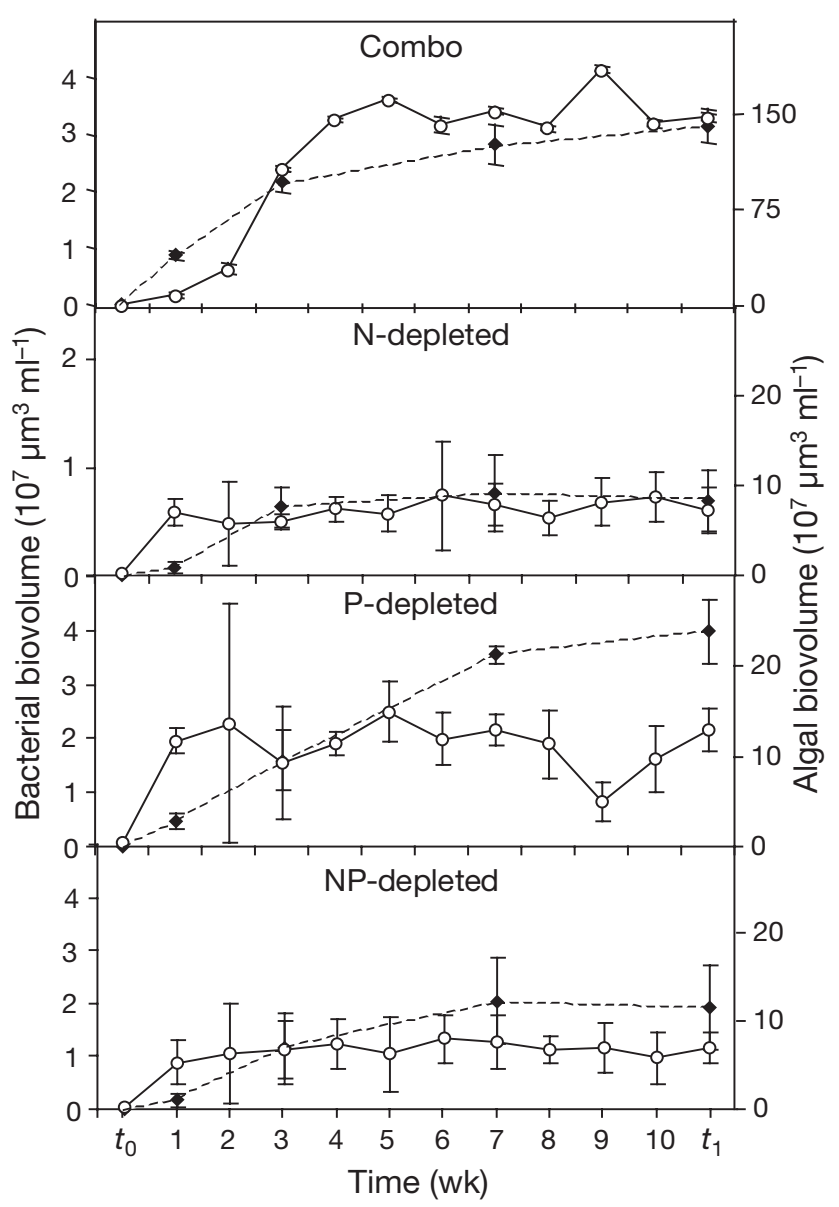

Fig. 2. Scenedesmus obliquus $(\mathrm{O})$ and bacterial $(\diamond)$ biovolume dynamics for Combo, N-depleted, P-depleted and NPdepleted treatments $($ mean $\pm \mathrm{SD})$

\section{Limitation of algal growth at steady-state}

As depicted in Fig. 4, the limitation tests revealed significant treatment effects on algal relative growth rates in all 4 media ( $\mathrm{p}<0.05)$. Post-hoc tests indicated that Scenedesmus obliquus was N-limited in the Combo and N-depleted treatments. For the P- and NPdepleted treatments, the results were less straightforward. For the P-depleted treatment, the P-test led to the highest relative growth rate and was significantly different from the N-tests, whereas the $\mathrm{N}$-, C- and NPC-tests did not significantly differ. However, the Ctest led to a higher relative growth rate than the $\mathrm{N}$-test. We exclude the possibility of direct limitation by glucose because glucose is neither a source of energy nor of $\mathrm{C}$ for $S$. obliquus. One can argue that, since glucose addition (Fig. 5) benefited the bacteria, it may have led to an increase in nutrient mineralisation and/or $\mathrm{CO}_{2}$ production, which may in turn have benefited the algae. In such a case, however, the NPC-test would have led to a higher relative growth rate than 


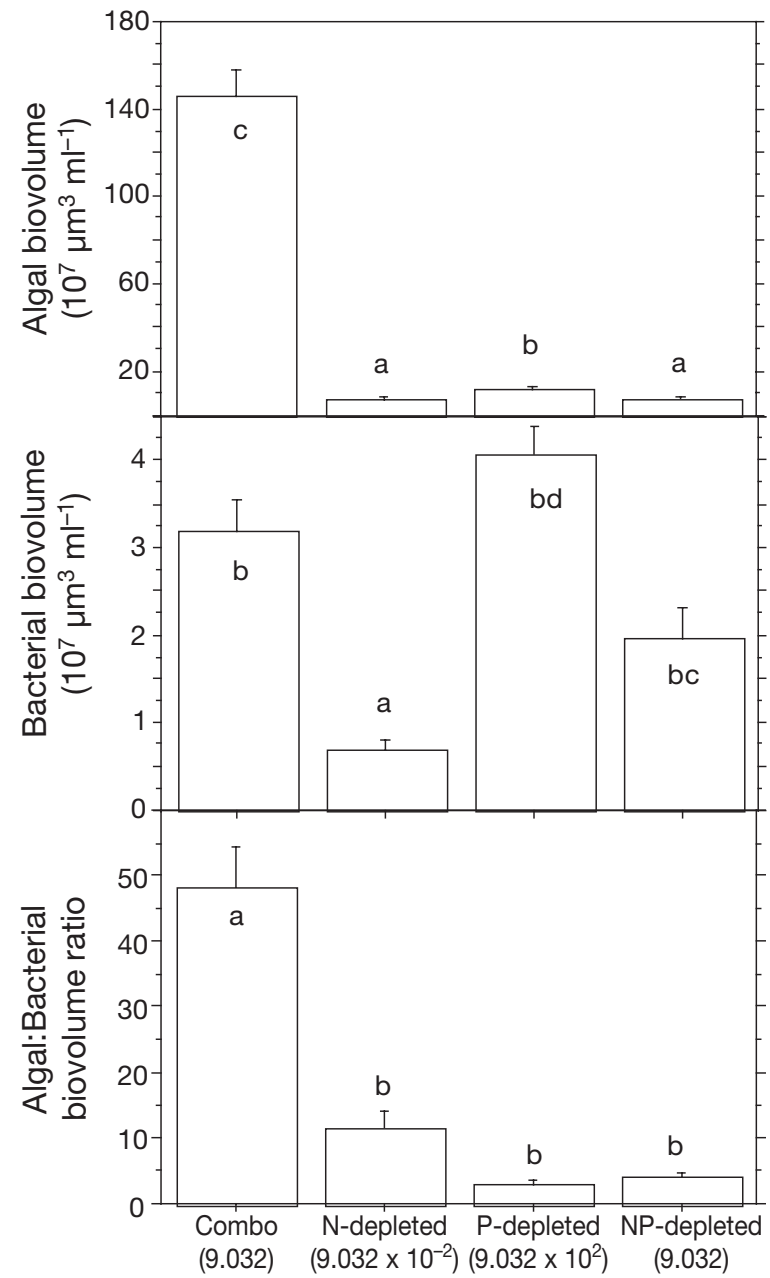

Fig. 3. Scenedesmus obliquus and bacterial biovolumes, and algal:bacterial biovolume ratio at time $t_{1}(11 \mathrm{wk}$ after inoculation) in the 4 treatments (Combo, N-depleted, P-depleted, and NP-depleted). Numbers in parentheses are the N:P ratios in the media. After log-transformation, ANOVA detected a significant effect of the treatments on biovolumes and the ratio $(\mathrm{p}<0.001)$. Letters $(\mathrm{a}, \mathrm{b}, \mathrm{c})$ indicate statistically homogeneous groups (post-hoc Scheffé's tests, $\mathrm{p}<0.05$ ). Values are means $+\mathrm{SE}$

the P-test, which was not the case. Therefore, we conclude that the algae were most likely P-limited. For the $\mathrm{NP}$-depleted treatment, the $\mathrm{C}$-, $\mathrm{N}$ - and P-tests were not significantly different, whereas the NPC-test was significantly different from the N-test and promoted a higher algal relative growth rate. The relative growth rate was higher in the $\mathrm{C}$ - and $\mathrm{N}$-tests than in the P-test. We conclude that the algae were most likely co-limited by $\mathrm{N}, \mathrm{P}$, and $\mathrm{C}$, with a stronger limitation by $\mathrm{N}$, and possibly by $\mathrm{CO}_{2}$ in the limitation test flask. However, it should be noted that, in contrast to the limitation test flasks, the microcosms received constant air bubbling. It is therefore unlikely that the algae were $\mathrm{CO}_{2}$-limited in the microcosms.

\section{Limitation of bacterial growth at steady-state}

As depicted in Fig. 5, the limitation tests revealed significant treatment effects on bacterial relative growth rates in all 4 media ( $p<0.01)$. In the depleted media (N-, P- and NP-depleted) post-hoc tests indicated that bacteria were clearly co-limited by $\mathrm{C}$ and at least one nutrient. We observed the same trend in the Combo medium, although there was no significant difference between the $\mathrm{C}$ - and the NPC-addition, which suggests that bacteria were closer to strict limitation by $\mathrm{C}$.

\section{DISCUSSION}

\section{Robustness of the coexistence}

In all stoichiometric treatments, both Scenedesmus obliquus and the bacteria displayed a growth phase after inoculation, followed by a plateau phase (steadystate), indicating stable coexistence over time. At steady-state, algal and bacterial biomasses varied across the treatments. P-depletion led to higher biomasses for both $S$. obliquus and the bacteria, while higher concentrations of both $\mathrm{N}$ and $\mathrm{P}$ led to an increase in algal biomass only. The limitation status of S. obliquus varied across the treatments. As expected, the N-depleted medium led to N-limitation and the Pdepleted medium led to P-limitation, whereas the more balanced (in terms of N:P ratio) Combo and NPdepleted media led to N-limitation and co-limitation by both $\mathrm{N}$ and $\mathrm{P}$, respectively. Hence, our goal to 'shake up the system' with strong stoichiometric constraints in order to address the robustness of the coexistence of $S$. obliquus and bacteria was fulfilled. Based on recent studies performed with the same experimental setup, Danger et al. $(2007 \mathrm{a}, \mathrm{b})$ discuss the functional causes for the variations of the limitation status of $S$. obliquus across stoichiometric treatments in more detail. In particular, they show that bacteria can indirectly affect the nutrient status of algae by (a) differential storing of nutrients in their biomass and (b) providing $\mathrm{CO}_{2}$, which is a potential limiting factor for algae in eutrophic media.

In their review of lake ecosystems, Downing \& McCauley (1992) reported that the ratio of total N:total $\mathrm{P}$ at the scale of whole lakes varied from $<1$ to $>250$. Oligotrophic lakes showed typical N:P ratios of 95 and a total $\mathrm{P}$ concentration of $2 \mu \mathrm{g} \mathrm{l^{-1 }}$, while eutrophic lakes showed typical N:P ratios of 23 and a total P concentration of $50 \mu \mathrm{g} \mathrm{l}^{-1}$. In our experiment, total $\mathrm{N}: \mathrm{P}$ ratios varied from 0.09032 (N-depleted medium) to 9032 (Pdepleted medium), which is much higher than in natural lakes. The concentration of total P was $15.5 \mathrm{\mu g} \mathrm{l}^{-1}$ 

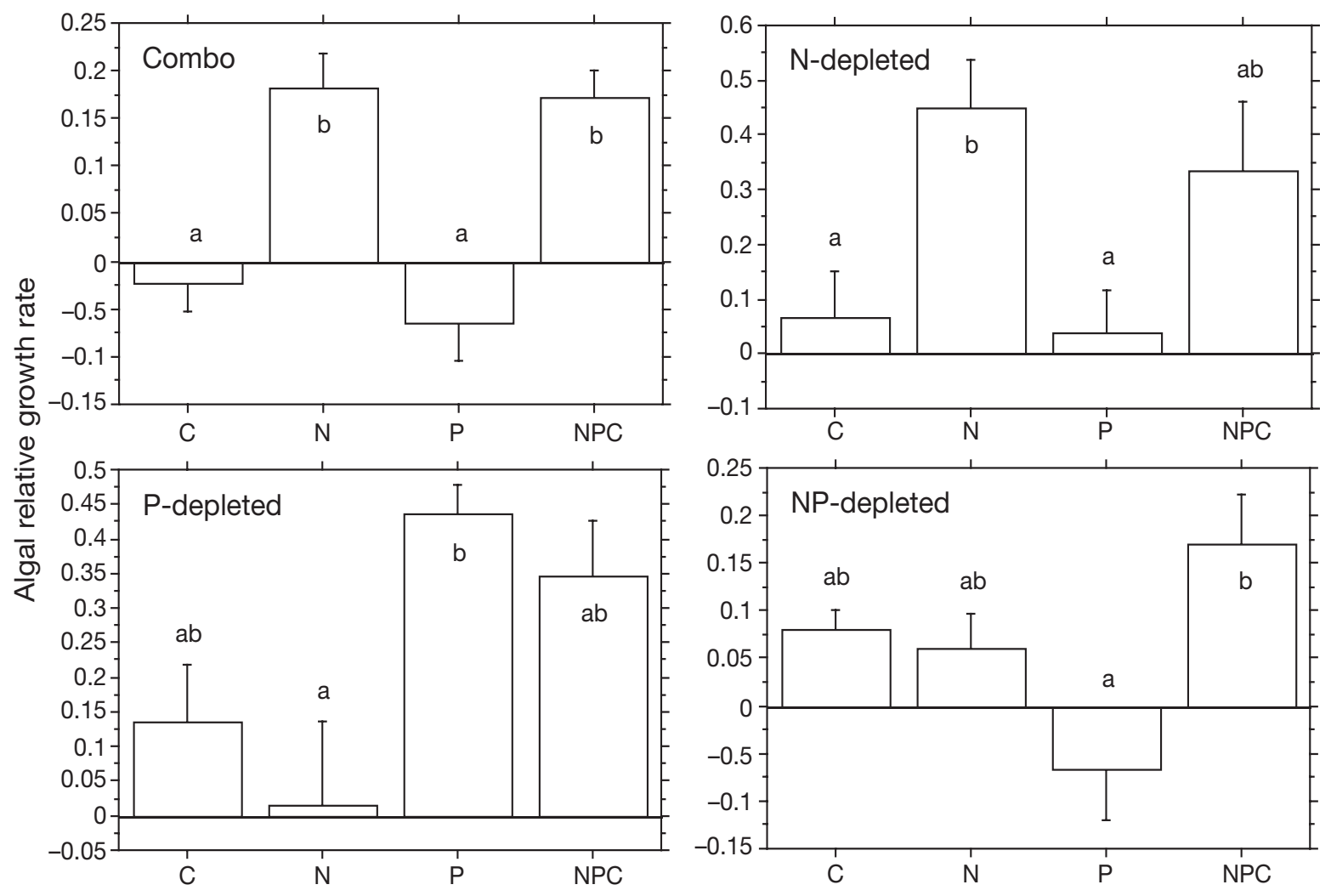

Fig. 4. Scenedesmus obliquus. Relative growth rates (= log of density in the test over density in the control at time $\left.t_{2}\right)$ in the 4 limitation tests (C, N, P, NPC) for each stoichiometric treatment (Combo, N-depleted, P-depleted and NP-depleted). ANOVA detected a significant effect of the tests $(\mathrm{p}<0.05)$. The block effect (microcosm) was significant and therefore corrected for the Combo, the N-depleted and the P-depleted treatments. Letters $(a, b)$ indicate statistically homogeneous groups (post-hoc Scheffé's tests, $\mathrm{p}<0.05$ ). Values are means + SE

for the P- and NP-depleted media, which corresponds to the P-level usually observed in slightly oligotrophic lakes. For the Combo and N-depleted media, total P reached $1550 \mathrm{\mu g} \mathrm{l}^{-1}$, which corresponds to a hypereutrophic state probably never achieved in nature. Hence, stoichiometric constraints in our experiment probably covered much of what is commonly encountered in nature, except for pronounced oligotrophy.

In all microcosms, and despite the absence of factors such as spacial heterogeneity (the medium was continuously stirred) or predation that would have prevented competitive exclusion, algae and bacteria coexisted in the long-term and bacteria performed efficient nutrient recycling. Although they were probably present in the microcosms, viruses did not control bacterial or algal biomasses. Indeed, algal and bacterial biomasses clearly showed a response to resource addition in the limitation tests, which is in accordance with former theoretical studies suggesting that viruses cannot control the total bacterial biomass in the water column (Thingstad 2000). Hence, viruses could not act as fac- tors preventing competitive exclusion. In the light of these results, we conclude that our microcosms were suitable to test the carbon hypothesis, because (1) algae and bacteria coexisted at steady-state, (2) the algae were nutrient-limited and relied on nutrient cycling by bacteria, and (3) factors preventing competitive exclusion were absent.

\section{Validation of the carbon co-limitation hypothesis}

Bacterial communities appeared to be co-limited by $\mathrm{C}$ and the nutrients ( $\mathrm{N}$ and/or $\mathrm{P}$ ) in all 4 stoichiometric treatments. As stated in the 'Introduction', co-limitation of bacteria by $\mathrm{C}$ and the nutrients $\mathrm{N}$ and $\mathrm{P}$ is not inconsistent with the carbon hypothesis. Indeed, colimitation represents a specific case of the carbon hypothesis (the carbon co-limitation hypothesis) in which the algae and the bacteria have the same competitive ability for the nutrient. Hence, we conclude that our experimental results validate the carbon co- 


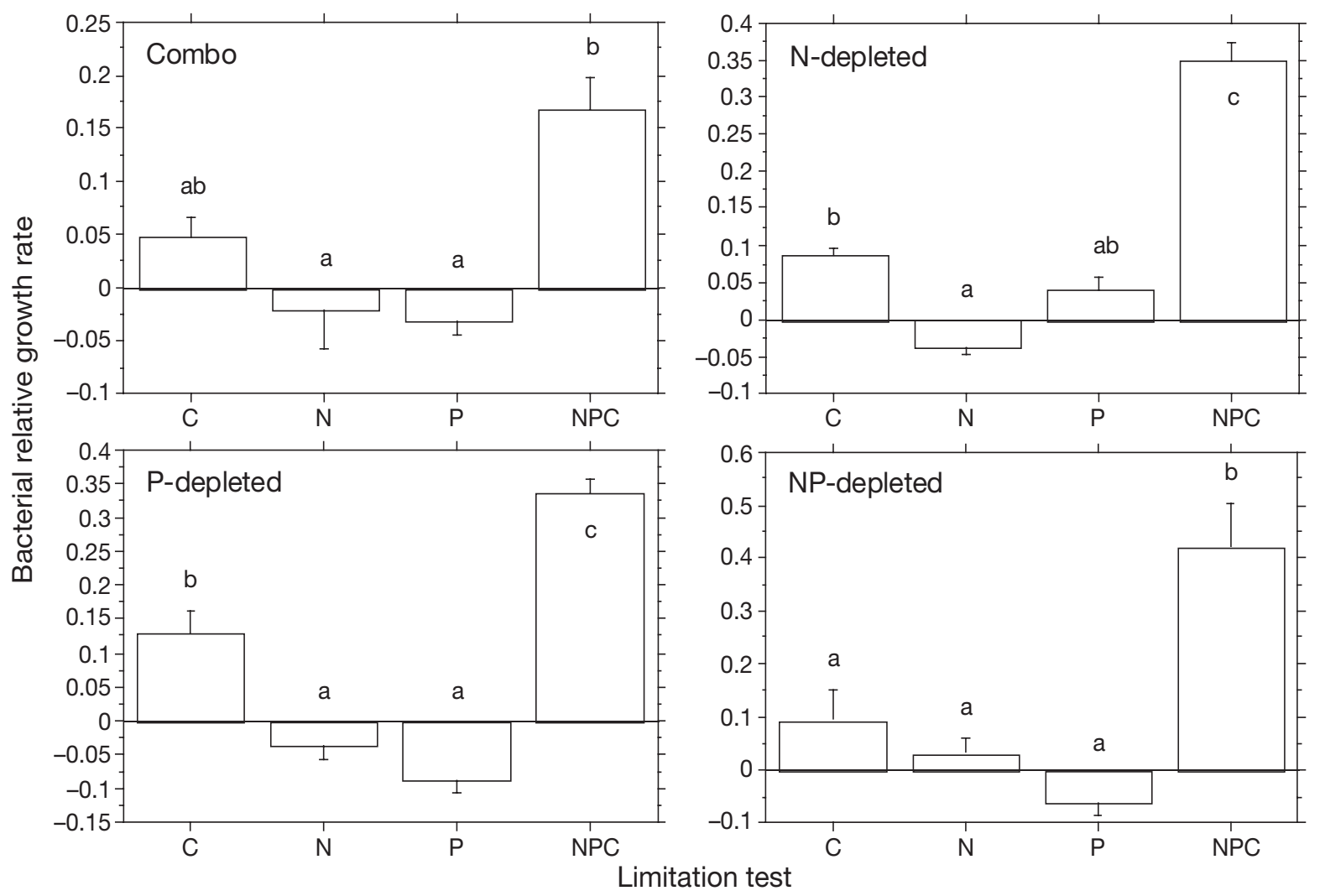

Fig. 5. Bacterial relative growth rates ( $=\log$ of biovolume in the test over biovolume in the control at time $\left.t_{2}\right)$ in the 4 limitation tests (C, N, P, NPC) for each stoichiometric treatment (Combo, N-depleted, P-depleted and NP-depleted). The ANOVA detected a significant effect of the tests $(p<0.01)$. The block effect (microcosm) was significant and therefore corrected only for the NP-depleted medium. Letters $(a, b, c)$ indicate statistically homogeneous groups (post-hoc Scheffé's tests, $p<0.05$ ). Values are means + SE

limitation hypothesis in all situations tested, whether nutrient availability was high (Combo medium) or low (depleted media), whether the algal to bacterial biomass ratio was high (Combo) or low (P), and whether the algae were limited by $\mathrm{N}$ (Combo and $\mathrm{N}$-depleted media), P (P-depleted medium) or co-limited by $\mathrm{N}$ and P (NP-depleted medium).

Co-limitation of bacteria in all our treatments is consistent with the hypothesis that competitive exclusion should select for dominant species which are co-limited (Cherif \& Loreau 2007). We depict the competitive exclusion mechanism in Fig. $1 \mathrm{C}, \mathrm{D}$, derived from the more general formulation proposed by Schade et al. (2005). Note that this mechanism relies on the assumption that there is a large pool of available phenotypes in the bacterial community, which includes the co-limited phenotypes that end up being dominant. In our experiment, the initial bacterial community was probably diverse, since it came from a natural environment. In addition, the duration of the experiment (11 wk) was probably sufficient to allow for the selection of mutants. However, one cannot exclude that other non-exclusive mechanisms could have led to co-limitation in our experiment, e.g. phenotypic plasticity, as hypothesised in the case of vascular plants (Rastetter \& Shaver 1992). However, recent experimental results using a similar microcosm setup support the species replacement mechanism (Leflaive et al. 2008, Danger et al. 2008).

\section{CONCLUSIONS}

As far as they can be generalised, our results support the fact that algae and bacteria stably coexist when isolated from other functional groups. Thus, it seems that additional functional diversity is not necessary for the long-term persistence of primary production and nutrient recycling in the water column. Although the carbon hypothesis only represents one step in the complex chain of mechanisms that rule food web dynamics in the water column (e.g. Thingstad \& Rassoulzadegan 1995, Daufresne \& Loreau 2001) it has several important implications to keep in mind when addressing plankton dynamics and the cycles of nutrients and $\mathrm{C}$ in 
the water column. Among these implications is the priority of decomposition over primary production when exogenous organic $\mathrm{C}$ is supplied (Daufresne \& Loreau 2001), which appears to play an important role in the functioning of freshwater ecosystems, especially for those that are subject to important organic inputs from watersheds (Hessen et al. 1994, Jansson 1998).

Acknowledgements. This study was supported by the CNRS and was partly funded by the PNBC (ACI-ECCO) French National Program. M.L. acknowledges a Discovery grant from the National Sciences and Engineering Research Council of Canada. We are grateful to T. F. Thingstad for his comments on a previous version of the manuscript and to F. Rassoulzadegan and 3 anonymous reviewers for their useful suggestions.

\section{LITERATURE CITED}

Bird DF, Kalff J (1984) Empirical relationships between bacterial abundance and chlorophyll concentration in fresh and marine waters. Can J Fish Aquat Sci 41:1015-1023

Bosatta E, Berendse F (1984) Energy or nutrient regulation of decomposition: implications for the mineralization-immobilization response to perturbations. Soil Biol Biochem 16: 63-67

Bratbak G, Thingstad TF (1985) Phytoplankton-bacteria interactions: an apparent paradox? Analysis of a model system with both competition and commensalism. Mar Ecol Prog Ser 25:23-30

Cherif M, Loreau M (2007) Stoichiometric constraints on resource use, competitive interactions, and element cycling in microbial decomposers. Am Nat 169:709-724

Currie DJ (1990) Large-scale variability and interactions among phytoplankton, bacterioplankton, and phosphorus. Limnol Oceanogr 35:1437-1455

Currie DJ, Kalff J (1984a) A comparison of the abilities of freshwater algae and bacteria to acquire and retain phosphorus. Limnol Oceanogr 29:298-310

Currie DJ, Kalff J (1984b) The relative importance of bacterioplankton and phytoplancton in phosphorus uptake in freshwater. Limnol Oceanogr 29:311-321

Danger M, Oumarou C, Benest D, Lacroix G (2007a) Bacteria can control stoichiometry and nutrient limitation of phytoplankton. Funct Ecol 21:202-210

Danger M, Leflaive J, Oumarou C, Ten-Hage L, Lacroix G (2007b) Control of phytoplankton-bacteria interactions by stoichiometric constraints. Oikos 116:1079-1086

Danger M, Daufresne T, Lucas F, Pissard S, Lacroix G (2008) Does Liebig's law of the minimum scale up from species to communities? Oikos 117:1741-1751

Daufresne T, Loreau M (2001) Ecological stoichiometry, indirect interactions between primary producers and decomposers, and the persistence of ecosystems. Ecology 82: 3069-3082

Downing JA, McCauley E (1992) The nitrogen:phosphorus relationship in lakes. Limnol Oceanogr 37:936-945

Golterman HL (1964) Mineralization of algae under sterile conditions or by bacterial breakdown. Verh Int Verein Limnol 15:544-548

- Hardin G (1960) The competitive exclusion principle. Science 131:1292-1297

Havskum H, Thingstad TF, Sharek R, Peters F and others (2003) Silicate and labile DOC interfere in structuring the microbial food web via algal-bacterial competition for mineral nutrients: results of a mesocosm experiment. Limnol Oceanogr 48:129-140

> Hessen DO, Nygaard K, Salonen K, Vähätalo A (1994) The effect of substrate stoichiometry on microbial activity and carbon degradation in humic lakes. Environ Int 20:67-76

Jannasch HW (1964) Microbial decomposition in natural waters as determined in steady state systems. Verh Int Verein Limnol 15:562-568

Jansson M (1998) Nutrient limitation and the bacteria-phytoplankton interactions in humic lakes. In: Hessen DO, Tranvik LJ (eds) Aquatic humic substances: ecology and biochemistry. Ecological studies, Vol 133. SpringerVerlag, Berlin, p 177-194

Joint I, Henriksen P, Fonnes GA, Bourne D, Thingstad TF, Riemann B (2002) Competition for inorganic nutrients between phytoplankton and bacterioplankton in nutrient manipulated mesocosms. Aquat Microb Ecol 29:145-159

Kilham SS, Kreeger DA, Lynn SG, Goulden CE, Herrera L (1998) COMBO: a defined freshwater culture medium for algae and zooplankton. Hydrobiologia 377:147-159

Kirchman DL, Richard GK (1990) Carbon limitation of ammonium uptake by heterotrophic bacteria in the subarctic Pacific. Limnol Oceanogr 35:1258-1266

> Leflaive J, Danger M, Lacroix G, Lyautey E, Oumarou C, TenHage L (2008) Nutrient effects on the genetic and functional diversity of aquatic bacterial communities. FEMS Microbiol Ecol 66:379-390

Morris DP, William MLJ (1992) Nutrient limitation of bacterioplankton growth in Lake Dillon, Colorado. Limnol Oceanogr 37:1179-1192

> Pengerud B, Skjoldal EF, Thingstad TF (1987) The reciprocal interaction between degradation of glucose and ecosystem structure. Studies in mixed chemostat cultures of marine bacteria, algae, and bacterivorous nanoflagellates. Mar Ecol Prog Ser 35:111-117

Pomeroy LR (1970) The strategy of mineral cycling. Annu Rev Ecol Syst 1:171-190

Porter KG, Feig YS (1980) The use of DAPI for identifying and counting aquatic microflora. Limnol Oceanogr 25:943-948

Rastetter EB, Shaver GR (1992) A model of multiple-element limitation for acclimating vegetation. Ecology 73: $1157-1174$

Rhee GY (1972) Competition between an alga and an aquatic bacterium for phosphate. Limnol Oceanogr 17:505-514

Rhee GY (1973) A continuous culture study of phosphate uptake, growth rate and polyphosphate in Scenedesmus sp. J Phycol 9:495-506

Rhee GY (1974) Phosphate uptake under nitrate limitation by Scenedesmus sp. and its ecological implications. J Phycol 10:470-475

Rhee GY (1978) Effects of N:P atomic ratios and nitrate limitation on algal growth, cell composition, and nitrate uptake. Limnol Oceanogr 23:10-25

Schade JD, Espeleta JF, Klausmeier CA, McGroddy ME, Thomas SA, Zhang L (2005) A conceptual framework for ecosystem stoichiometry: balancing resource supply and demand. Oikos 109:40-51

Sterner RW, Elser JJ (2002) Ecological stoichiometry. The biology of elements from molecules to the biosphere. Princeton University Press, Princeton, NJ

Thingstad TF (2000) Elements of a theory for the mechanisms controlling abundance, diversity, and biogeochemical role of lytic bacterial viruses in aquatic systems. Limnol Oceanogr 45:1320-1328

Thingstad TF, Pengerud B (1985) Fate and effect of allochthonous organic material in aquatic microbial ecosystems. An 
analysis based on chemostat theory. Mar Ecol Prog Ser 21: $47-62$

Thingstad TF, Rassoulzadegan F (1995) Nutrient limitations, microbial food webs, and 'biological C-pumps': suggested interactions in a P-limited Mediterranean. Mar Ecol Prog Ser 117:299-306

Thingstad TF, Hagström $\AA$, Razoulzadegan F (1997) Accumulation of degradable DOC in surface waters: is it caused by a malfunctioning microbial loop? Limnol Oceanogr 42: 398-404

Thingstad TF, Zweifel UL, Rassoulzadegan F (1998) P limitation of heterotrophic bacteria and phytoplancton in the northwest Mediterranean. Limnol Oceanogr 43:88-94

Tilman D (1982) Resource competition and community structure. Monographs in population biology. Princeton University Press, Princeton, NJ

Tuomi P, Kuuppo P (1999) Viral lysis and grazing loss of bacteria in nutrient and carbon manipulated brackish water enclosures. J Plankt Res 21(5):923-937
Vadstein O (1998) Evaluation of competitive ability of two heterotrophic planktonic bacteria under phosphorus limitation. Aquat Microb Ecol 14:119-127

Vadstein O, Olsen Y (1989) Chemical composition and phosphate uptake kinetics of limnetic bacterial communities cultured in chemostats under phosphorus limitation. Limnol Oceanogr 34:939-946

Vadstein O, Harkjerr BO, Jensen A, Olsen Y, Reinertsen H (1989) Cycling of organic carbon in the photic zone of a eutrophic lake with special reference to the heterotrophic bacteria. Limnol Oceanogr 34:840-855

Van Wambeke F, Bianchi MA (1985) Dynamics of bacterial community and qualitative evolution of heterotrophic bacteria during the growth and decomposition processes of phytoplankton in an experimental marine ecosystem. J Exp Mar Biol Ecol 86:119-137

Zohary T, Robarts RD (1998) Experimental study of microbial $\mathrm{P}$ limitation in the eastern Mediterranean. Limnol Oceanogr 43:387-395

Appendix 1. Outline of original model by Daufresne \& Loreau (2001) and derivation of the Zero Net Growth Isoclines (ZNGIs) from the model

The model is a modification of the Lotka-Volterra closed system model introduced by Daufresne \& Loreau (2001) and applied to an alga and a bacterium in a closed microcosm:

$$
\begin{aligned}
& \mathrm{d} P / \mathrm{d} t=n P N-e P \\
& \mathrm{~d} L / \mathrm{d} t=e P-\frac{\beta}{\alpha} G \\
& \mathrm{~d} D / \mathrm{d} t=G \min \left\{\left(\frac{\alpha}{(\alpha-\beta)} i D N ; \frac{\alpha}{\beta} \mathrm{d} L\right\}-m D\right. \\
& N=N_{\mathrm{T}}-(P+L+D) \\
& G=\min \left\{\left(\frac{\alpha}{(\alpha-\beta)} i D N_{i} \frac{\alpha}{\beta} \mathrm{d} L\right\}\right.
\end{aligned}
$$

where $P, L$ and $D$ represent the nutrient (e.g. nitrogen or phosphorus) stock in the algal biomass, the detritus and the bacterium, respectively, and $N$ represents the inorganic nutrient. The parameters $n, e, d$, and $m$ represent the rate of nutrient uptake by the alga, the algal mortality rate, the rate of detritus decomposition by the bacterium, and the bacterial mortality rate, respectively. Because the nutrient pool is finite (due to the closure of the nutrient cycle: no input or output from the microcosm), $N$ is a linear combination of the other variables, given the total amount of nutrient $N_{\mathrm{T}}$ provided to the microcosm before inoculation (time $t_{0}$ ). The parameters $\alpha$ and $\beta$ represent the ratio of carbon to nutrient in the alga and algal detritus biomasses, and in the bacterial biomass, respectively. Hence, from the detritus nutrient stock dynamics in Eq. (A1), one can deduce the detritus carbon stock dynamics:

$$
\alpha \mathrm{d} L / \mathrm{d} t=\alpha\left(e P-\frac{\beta}{\alpha} G\right)
$$

The rate of nutrient uptake by the bacterium, $\frac{\alpha}{\alpha-\beta} i$ depends both on the intrinsic rate of uptake $i$ and the need for a nutrient complement, given the difference of nutrient quota in the detritus and in the bacterial biomass. The coexistence steady-state is obtained by setting the 3 dynamic equations in Eq. (A1) to zero, assuming bacteria are carbon limited, i.e., $G=\frac{\alpha}{\beta} \mathrm{d} L\left({ }^{*}\right.$ denotes the value of a variable at
equilibrium):

$$
\begin{aligned}
& P^{*}=\frac{N_{\mathrm{T}}-N^{*}}{1+e / d+\alpha e / \beta m} ; \quad L^{*}=(e / d) P^{*} ; \\
& D^{*}{ }_{\text {bac }}=(\alpha e / \beta m) P^{*} ; \quad N^{*}{ }_{\text {alg }}=e / n
\end{aligned}
$$

Note that 'bac' and 'alg' in $D^{*}$ and $N^{*}$, respectively, highlight the fact that the bacterium is limited by the carbon contained in the detritus, whereas the alga is limited by the nutrient. In case of nutrient limitation for the bacterium, we refer to the steady-state value of $N$ as ' $N{ }^{*}$ bac' (see below).

In the nutrient versus organic carbon space, The Zero Net Growth Isocline (ZNGI, sensu Tilman 1982) for each competitor is given by the values of the limiting resources (here, nutrient and organic carbon for the bacterium and nutrient only for the alga) for which growth is balanced by mortality, i.e. by definition, when the biomass is at steady-state. The ZNGI is depicted by the single ' $N^{*}$ alg' line for the alga, whereas the bacterium's ZNGI is corner shaped, with the ' $a L^{* \prime}$ l line when the bacterium is carbon limited and the ' $N^{*}$ bac ' line when the bacterium is nutrient limited.

$N^{*}{ }_{\text {bac }}=\frac{m(\alpha-\beta)}{i \alpha}$ is obtained by setting the dynamic equation of the bacterium in Eq. (A1) to zero, assuming $G=\frac{\alpha}{\alpha-\beta} i D N$

The consumption vectors are, respectively (Tilman 1982), $\vec{c}_{\text {alg }}=\left(n P^{*} N^{*}, 0\right)$ for the alga, and $\vec{c}_{\text {bac }}=\mathrm{d} L^{*}[(\alpha-\beta) / \beta, \alpha]$ for the bacterium. Note that the algal consumption vector's slope is 0 , i.e., the consumption vector $\vec{C}_{\text {alg }}$ is horizontal. 